\title{
Economic analysis to optimize food plant patterns in Paloh Sub-district, Sambas District
}

\author{
Juliana C. Kilmanun", Rusli Burhansyah, and Riki Warman \\ Kalimantan Assessment Institute for Agricultural Technology, 78241, Indonesia
}

\begin{abstract}
The potential of land in The Paloh sub-district for the development of rice-mung beans is quite large. The rice and mung bean cropping patterns have been cultivated by farmers. The problems faced by farmers are the use of fertilizers that are not optimal, the use of superior seeds is still low. This study aims to (1) study the use of farm inputs, costs, and income, (2) analyze the optimal cropping patterns in food crop farming in The Paloh Sub-District. Sambas District. The analytical method used is farm analysis and optimization of cropping patterns using linear programming. The results showed that the rainy season rice cropping patterns and the dry season rice cropping patterns resulted in an income of IDR $87,071,580$ per year. Based on the optimization results, it was found that the rainy season rice was 0.61 ha and dry season rice was 0.88 ha.
\end{abstract}

\section{Introduction}

Population change and rapid urbanization, causing land and water resources to be very limited. Plant optimization has received wide attention in recent years. Mathematical models were developed to determine the optimal use of available resources to maximize net benefits which experienced several constraints. Land and water are key factors in the sustainable agricultural development of a nation [1]. One way to optimize agricultural business is with cropping patterns. The cropping pattern is defined as the proportion of plants that differ over a certain period. A change in cropping patterns means a change in the proportion of land use on different crops. It connotes mixed crops grown in a certain area in a certain year [2].

A multi-goal programming approach to determine optimal cropping patterns in the Jahro region, Iran in conditions of water deficit. The results of those research shows that cropping patterns can reduce water use and save additional costs without causing additional risks [3]. Karamouz [4] developed a simulation-optimization model of agricultural planning to optimize planting area, cropping patterns, and irrigation efficiency by taking into account the impacts of climate change. The results demonstrate the importance of using different tools and methods in assessing and allocating water resources in areas with limited water resources. Alabdulkader [5] developed a mathematical model to determine the optimal one-year cropping patterns in Saudi Arabia which aim to maximize the annual net profit of the agricultural sector and ensure efficient accumulation, scarce water resources, and fertile land among competing crops. The optimized cropping patterns resulted in about $53 \%$ savings in

\footnotetext{
* Corresponding author: julianakilmanuncorry@gmail.com
} 
water use and about a $48 \%$ reduction in the use of arable land compared to typical agricultural cropping patterns.

Kaur, et al [6] examined the optimization of rice cropping patterns to maximize the absorption and retention of groundwater in the Punjab area. The research was conducted in 2002-2003 on 170 farmer cooperators. The experimental design used a layered random method. The results show that there are groundwater savings of up to 25 percent without a decrease in crop production. This cotton rice cropping pattern increased production by 4 percent and saved groundwater by 26.55 percent. The SRI cropping patterns with inundation and drying of rice plants by direct planting is a technique for conserving water. Groves [9] studied cropping patterns related to land use and distribution of planting time. The study was carried out in 64 districts in Bangladesh using a structured questionnaire. 316 cropping patterns had been identified, 5 plant distributions contained rice covering about $51 \%$ of the area.

Burhansyah [8] conducted a study on cropping patterns of rice, mung beans, and vegetables in rainfed rice fields in The Paloh Sub-district. The results showed that "'the average arable area of 0.6 ha could be optimized with a combination of local rice farming during the rainy season. 0.6 ha. In the dry season, there is about 0.3 ha of superior rice, 0.1 ha of mung beans, 0.05 ha of mustard greens, 0.05 ha of chilies, and 0.1 ha of cucumber. The optimal solution can maximize farmers' income by IDR 34,818,000. To optimize the agricultural system, mung beans, and vegetables with an average land area of 0.6 ha, the recommended farming patterns in the dry season is 0.6 ha of local rice, 0.3 ha of superior dry season rice, 0.1 ha of mung beans, mustard greens 0.05 ha, 0.05 ha chili and 0.1 ha cucumber',

Paloh Sub-district is an area of Sambas District which is directly adjacent to neighboring Malaysia. The agricultural potential of rice food crops is around 8,002 ha. In addition to rice, mung bean plants are cultivated by farmers because the selling price is quite expensive. The harvested area for mung beans is around 1,376 ha, with a production of 1,043 tonnes and a productivity of 0.758 ton/ha [3]. The cropping patterns applied by farmers in the Paloh subdistrict include; the rainy season of local rice, the dry season of new high-yielding varieties of rice and mung beans. The problem at the farmer level is that there is no cropping patterns planning that maximizes profits. For this reason, research on cropping patterns that maximize farmers' income is needed. The purpose of this study was to determine the optimization of cropping patterns for food crops in The Paloh Sub-district, Sambas District.

\section{Research methods}

\subsection{Location and time}

The study was conducted in 3 villages in Paloh sub-district with the consideration that the three villages had more extensive rice, mung bean, and rice planting activities than the other villages. The villages include: Matang Danau Village, Tanah Hitam Village and Kalimantan Village. The research period was October to December 2019. The survey method focusing on a systematic method for collecting information from a population sample was applied to describe a quantitative description of the age of a larger population [9]. 


\subsection{Sampling methods}

The research was aimed at rice and mung bean farmers based on information from PPL Paloh Sub-district. Furthermore, to get farmers to become respondents, random sampling was carried out. The number of respondents was 60 people.

\subsection{Data analysis}

From the data collected, it is presented in tabular form. Data analyses used gross income dan net income analysis as follows [10].

$$
\begin{aligned}
G M & =G F I-T V C \\
N F I & =G F I-T V C-T F C
\end{aligned}
$$

$\begin{array}{ll}\text { GM } & =\text { Gross Margin } \\ \text { GFI } & =\text { Gross Farm Income } \\ \text { TVC } & =\text { Total Variable Cost } \\ \text { TFC } & =\text { Total Fixed Cost } / \text { ha } \\ \text { NFI } & =\text { Net Farm income/ha }\end{array}$

The QM linear programming for window v5 is used to solve the problem of optimizing the cropping patterns for rice and mung beans [11] with the following model:

\section{Purpose Function:}

The function that maximizes income from various activities (types of rice farming, mung beans) is mathematical as follows:

Maximize

$$
Z=C_{1} X_{1}+C_{2} X_{2}+\cdots C_{j} X_{J}
$$

$\mathrm{Cj}=$ the parameter used as the optimization criterion or the coefficient of change in the $\mathrm{j}$ decisionmaking in the objective function (coefficient of the objective function), which is the net income for each farming activity.

$\mathrm{Xj}=$ the variable of decision making or activity (which you want to look for), namely the type of rice, mung bean)

$\mathrm{Z}$ = value of decision-making criteria; an objective function; or optimized

\section{Constraint function:}

The constraint function is the availability of agricultural resources owned by farmers. Mathematically it is formulated as follows [8]:

$$
\begin{aligned}
& a_{11} X_{1}+a_{12} X_{2}+a_{13} X_{3}+\ldots \ldots \ldots \ldots+a_{1 j} X_{j} \leq b_{1} \\
& a_{21} X_{1}+a_{22} X_{2}+a_{23} X_{3}+\ldots \ldots \ldots \ldots+a_{2 j} X_{j} \leq b_{2} \\
& a_{31} X_{1}+a_{32} X_{2}+a_{33} X_{3}+\ldots \ldots \ldots \ldots+a_{3 j} X_{j} \leq b_{3} \\
& { }_{a i 1} X_{1}+a_{12} X_{2}+a_{i 3} X_{3}+\ldots \ldots \ldots \ldots \ldots .+a_{i j} X_{j} \leq b_{i}
\end{aligned}
$$

and non-negative terms

$$
X j \leq 0, \text { for } j=1,2, \ldots \ldots, n
$$

Hij = technology coefficient of the $\mathrm{j}$ decision-making variable in the $\mathrm{i}$ constraint, namely use of agricultural resources per ha.

bi $\quad$ finite $\mathrm{i}$ the resource that addresses activities. 
$\mathrm{Xi}=$ variable of decision making or activity, that is, type rainy season rice farming, mung bean farming, dry season rice farming.

I = the number of agricultural resources that are constrained.

$\mathrm{J} \quad=$ number of decision-making variables (activity)

Furthermore, the linear programming planning model is solved using the simplex method with a linear programming matrix model. Apart from the optimal solution, a sensitivity or post optimal analysis was also carried out.

\section{Results and discussions}

\subsection{Geographical location, climate, and planting patterns}

Geographically, Paloh sub-district is located between 1035'35 " to 2005 '43' North Latitude and $109038^{\prime} 56$ "to 1090 28'27" East Longitude. The Paloh Sub-district is located in the north of Sambas District which is directly adjacent to the Sarawak State of eastern Malaysia. This sub-district is a coastal area that has the longest coastline in the Sambas district. Paloh subdistrict has an area of $1,148.84 \mathrm{~km}^{2}(114,884 \mathrm{ha})$ or 17.96 percent of the area of Sambas district [12].

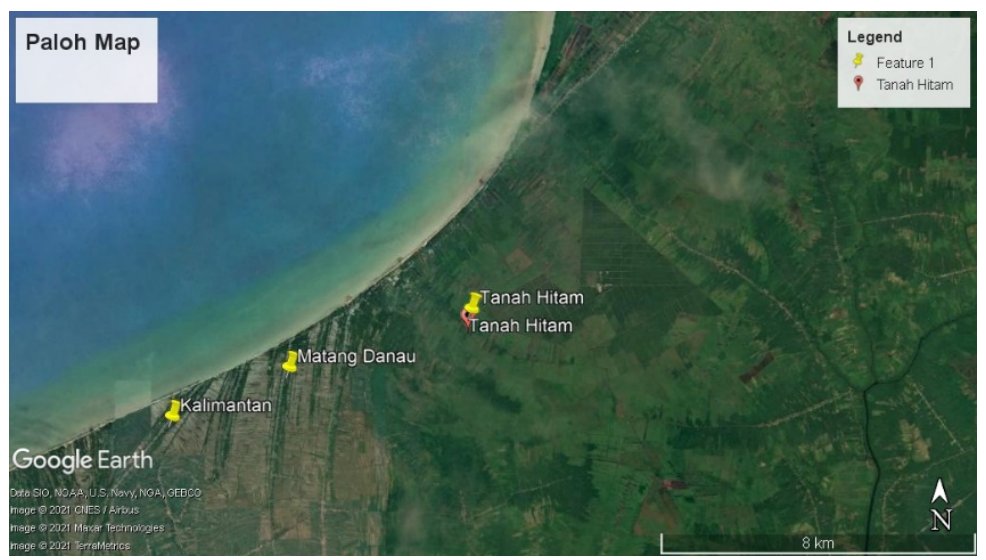

Fig.1 Map of Paloh Sub-district

Based on the average rainfall data for 2011-2018 in Paloh Sub-district, the average per month is around $223 \mathrm{~mm}$. The rainy season starts from September/October to February. The dry season starts from March/April to August (Figure 2)

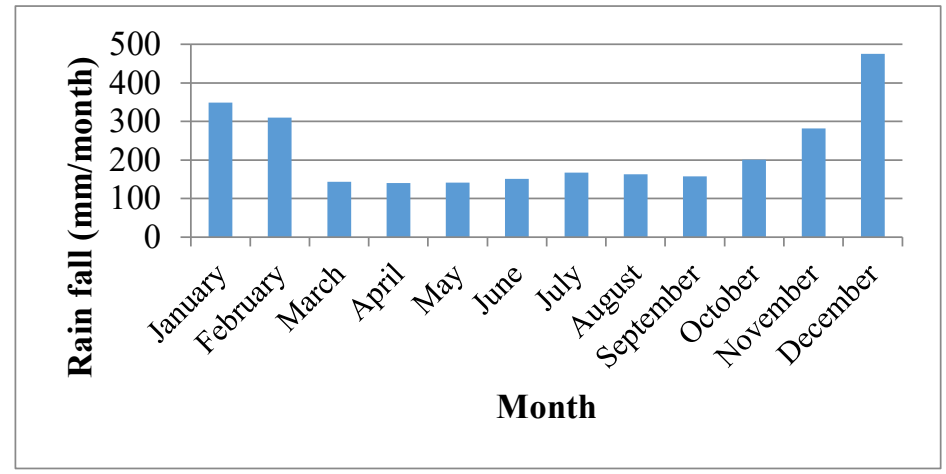

Fig. 2. Average rainfall in 2011-2018 in Paloh Subdistrict 
Based on the results of the Focus Group Discussion at the farmer level, the cropping patterns during the rainy and dry seasons obtained the following cropping patterns (Figure 3). The dominant types of food commodities cultivated by farmers in the Paloh sub-district are local rice, new superior varieties of rice, and mung beans. Generally, the cropping pattern applied by farmers is monoculture. In the rainy season, the land is planted with local rice, in the dry season, it is planted with new superior varieties of rice. Mung beans are planted after the rainy season in February. Farmers grow mung beans using local seeds. On average, farmers work on their land for mung bean cultivation, about 1 bag $(0.16 \mathrm{ha})$. Mung bean cultivation is still simple, farmers plant mung beans after planting rice in the rainy season. The cultivation of mung beans does not use chemical fertilizers since farmers think that the former paddy fields still contain fertilizer. Planting without tillage and burned rice straw and harvest age 65 days.

\begin{tabular}{|c|c|c|c|c|c|c|c|c|c|c|c|c|}
\hline & 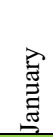 & 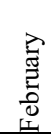 & 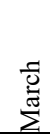 & $\overline{\mathrm{c}}$ & $\sum^{\mathrm{J}}$ & $\Xi$ & $\vec{\partial}$ & 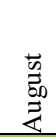 & 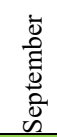 & $\begin{array}{l}\overline{0} \\
\stackrel{0}{0} \\
\delta\end{array}$ & $\begin{array}{l}\bar{\delta} \\
\bar{E} \\
\overline{0} \\
z\end{array}$ & 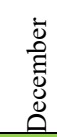 \\
\hline $\begin{array}{l}\text { Rice-Rainy } \\
\text { Season }\end{array}$ & & & & & & & & & & & & \\
\hline Mungbeans & & & & & & & & & & & & \\
\hline Rice-Dry Season & & & & & & & & & & & & \\
\hline
\end{tabular}

Fig. 3. Cropping Patterns in Paloh Sub-district

The results of the analysis of farmers' income per hectare based on the type of farming carried out by farmers are presented in Table 1. From the results of the income analysis (Table 1), it is known that the largest income from three farming activities per hectare of new highyielding rice varieties in the dry season is IDR $31,840,000$ with $\mathrm{R} / \mathrm{C}=2.17$. The results of the analysis of rice farming income for the rainy season were IDR $21,500.00, \mathrm{R} / \mathrm{C}=1.72$. Of all the farming activities, mung bean farming provided the smallest income, namely IDR. $11,237,500$. Mung bean farming income is due to low productivity ( 0.8 tonnes/ha). The potential for mung bean production can reach 2 tons/ha [13]. The productivity of green beans is low because of (1) the Lack of use of certified superior seeds, (2). availability of quality green bean seeds, (3) and application of technology that is not yet optimal.

Farm area, production cost, and revenue and cost ratio ( $\mathrm{R} / \mathrm{C}$ ratio) are important aspects of farming planning. The issue of farm area and production costs will be important in determining the type of crop to be cultivated if farmers are faced with limited resources, both land area, capital for production facilities, and paying labor wages. The implication is that although a farm can provide the highest income, it is not necessarily the best choice to implement because the area and type of farming are related to production costs. How to determine the type of farming activity by considering the limited agricultural resources that are owned so that farming is optimal (can maximize income). The results of the analysis applying linear programming are presented below to solve this problem. 
Table 1. Costs and Income from the rice-mung-bean-rice cropping patterns in Paloh Subdistrict, 2019

\begin{tabular}{|c|c|c|c|c|c|c|}
\hline \multirow{2}{*}{$\begin{array}{c}\text { Description } \\
\text { of } \\
\text { activities }\end{array}$} & \multicolumn{2}{|c|}{ Rainy season rice } & \multicolumn{2}{c|}{ Mung bean } & \multicolumn{2}{c|}{ Dry season rice } \\
\cline { 2 - 6 } & Input & Output & Input & Output & Input & Output \\
\hline $\begin{array}{c}\text { Material } \\
\text { cost }\end{array}$ & $3,176,263$ & & $2,301,000$ & & $7,159,500$ & \\
\hline $\begin{array}{c}\text { Labour } \\
\text { wage }\end{array}$ & $9,310,000$ & & $4,860,000$ & & $7,543,000$ & \\
\hline Total Cost & $12,486,263$ & & $7,161,000$ & & $14,702,500$ & \\
\hline production & & 4,778 & & 802.68 & 7,960 & 7,960 \\
\hline Price & & 4,500 & & 14.00 & 4,000 & 4,000 \\
\hline & & & & 802.68 & & \\
\hline Price & & & & 14,000 & & \\
\hline $\begin{array}{c}\text { Total } \\
\text { Revenue }\end{array}$ & $21,500,000$ & & $11,237,500$ & & $31,840,000$ \\
\hline Profit & & $9,013,737$ & & $4,076,500$ & & $17,137,500$ \\
\hline R/C Ratio & & 1.72 & & 1.57 & & 2.17 \\
\hline
\end{tabular}

\subsection{Farming optimization}

The results of the optimization analysis include solving primal and dual problems as well as sensitivity analysis. This analysis considers 3 farming activities with 4 kinds of agricultural resources (land area, labor requirement, cost farming, and uptake of mung bean market). From the analysis, farmers planted 0.61 ha of rainy season rice and 0.83 ha of dry season rice. The average farmer's land ownership is 1.44 ha.

Primal Completion. The results of the analysis with linear programming obtained an optimal solution or one that maximizes farmer's income, namely rainy season rice planting with an area of 0.61 ha and dry season rice cultivation with an area of 0.83 ha. Based on the primal solution (Table 2), 2 activities fall into the base with $\mathrm{Z} \max =87,071,590$. This means that the rainy season rice planting patterns with an area of 0.61 ha and the dry season rice planting patterns with an arable area of 0.66 ha can maximize the income of farmers in the Paloh sub-district, which is IDR. 87,071,590 due to the increased production. It means that the selected farming activities in the optimal solution include rainy season rice and dry season rice farming. The average arable area of 0.61 ha for rainy season rice and 0.83 ha of arable area for dry season rice will provide maximum total income with an allocation of this value. Both activities were carried out in a monoculture pattern at different seasons. The combination of farming activities with the arrangement of the farm area will maximize the total income of the farmers, which is IDR 87,071,590.

The value of cost reduction activities included in the basis is 0 , meaning that the entrepreneurial scale of the activity has provided maximum income and is not profitable if the scale of exploitation is increased. Based on the results of the primal settlement analysis, the suggested scale of activity is indicated by the value as previously described. Farming activities that are not included in the basis (non-basis) have a reduced cost value. This shows that if resources are allocated to these activities, each unit of allocation will reduce the total income in the optimal solution by the value of the reduced cost. Therefore, the mung bean farming activity is not included in the optimal solution (value is equal to zero). 
Table 2. Results of Linear Programming Analysis on Primal Solutions

\begin{tabular}{|c|c|c|c|c|}
\hline Variable & Farming Activity & Status & Value(ha) & $\begin{array}{c}\text { Reduced } \\
\text { Cost(IDR) }\end{array}$ \\
\hline X1 & Rice-rainy season & Basis & 0.61 & 0 \\
\hline X2 & Mung bean & Non Basis & 0 & $7,067,491$ \\
\hline X3 & Rice-dry season & Basis & 0.83 & 0 \\
\hline \multicolumn{5}{|c|}{$\begin{array}{c}\text { Final Optimal Solution } \\
\text { Z max=87.071.590 }\end{array}$} \\
\hline
\end{tabular}

\subsection{Dual settlement}

In addition to the primal solution which points to the optimal solution of the objective function, important information obtained from the results of the optimization analysis is an evaluation of the use of agricultural resources shown in the dual solution (Table 3). In Table 3 , there are 4 existing agricultural resources among others namely land area, labor requirements, cost farming, and uptake of the mung bean market. There are 2 agricultural resources with the binding status, while other resources are non-binding. Agricultural resources that have binding status indicate that these resources are limited and used up in optimal solutions ( slack value $=$ zero) or there is no residue (Table 3 ). These used agricultural resources include the need for labor and farming costs (dual value/shadow price) as shown in Table 3. In theory, production is referred to the marginal value product. The dual value states that each additional resource use of one activity unit will increase the optimal value of the dual value. The dual value of the need for labor, meaning that every addition of 1 worker will increase the availability of labor by 1,161 workdays. While the dual value of farming costs is 1.18 , which means that each additional farming cost (other constant resources) will increase the optimal income solution by IDR. 87,071,590. Other resources that have a nonbinding status mean that the resource still has slack or is overused or not used because it is not included in the optimal solution so that the dual value is equal to zero. This means that the additional use of these resources does not increase the income of the optimal solution.

Table 3. The Results of Linear Programming Analysis in Dual Design

\begin{tabular}{|c|c|c|c|c|c|}
\hline \multirow{2}{*}{ Resources } & \multicolumn{2}{|c|}{ Constraints } & \multirow{2}{*}{ Status } & \multirow{2}{*}{$\begin{array}{c}\text { Slack/ } \\
\text { SuIDRlus }\end{array}$} & \multirow{2}{*}{$\begin{array}{l}\text { Dual Value/ } \\
\text { Shadow Price }\end{array}$} \\
\hline & Unit & Symbol & & & \\
\hline Land area & ha & $\mathrm{C} 1$ & Non-Binding & 3,497 & 0 \\
\hline $\begin{array}{l}\text { Labor } \\
\text { requirements }\end{array}$ & $\mathrm{HOK}$ & $\mathrm{C} 2$ & Binding & 0 & $1.161,16$ \\
\hline Cost farming & IDR & C3 & Binding & 0 & 1,18 \\
\hline $\begin{array}{l}\text { Uptake of the } \\
\text { mung bean } \\
\text { market }\end{array}$ & $\%$ & $\mathrm{C} 4$ & Non-Binding & 0.8 & \\
\hline
\end{tabular}

\subsection{Sensitivity analysis}

Sensitivity analysis is used to identify uncertain critical variables and was adopted in the uncertainty analysis of the Monte Carlo Simulation that was developed. The method for sensitivity analysis cannot be expected to be the same for all models [14]. The purpose of the sensitivity analysis is to reduce the calculation and avoid recalculation if there are changes in one or more coefficients when the optimal solution has been achieved. On the completion of the objective row ranges (Table 4). It can be seen that from activities that are sensitive to changes in income, the rice rainy season (X1) has a minimum limit of optimal programs that 
is more sensitive to decreased income than other activities because it has a sensitivity range of at least $19,3 \%$. The activity X3 (rice dry season) is less sensitive to decreased income because it has a wider range of sensitivity (allowable decrease), namely $100 \%$.

Table 4. The value of the sensitivity range of the objective function coefficients in the objective row ranges objective Coefficient Ranges

\begin{tabular}{|c|c|c|c|c|c|c|}
\hline \multicolumn{2}{|c|}{ Activities } & $\begin{array}{c}\text { Lower } \\
\text { Limit }\end{array}$ & $\begin{array}{c}\text { Current } \\
\text { Values }\end{array}$ & $\begin{array}{c}\text { Upper } \\
\text { Limit }\end{array}$ & $\begin{array}{c}\text { Allowable } \\
\text { Increase }\end{array}$ & $\begin{array}{c}\text { Allowable } \\
\text { Decrease }\end{array}$ \\
\hline Com & Symbol & & & & & \\
\hline $\begin{array}{c}\text { Rice } \\
\text { Rainy } \\
\text { Season }\end{array}$ & $\mathrm{X} 1$ & $2,978,482$ & $21,150,000$ & No Limit & No Limit & $2,978,482$ \\
\hline $\begin{array}{c}\text { Mung } \\
\text { bean }\end{array}$ & $\mathrm{X} 2$ & No Limit & $11,237,500$ & $18,304,990$ & $18.304,990$ & No Limit \\
\hline $\begin{array}{c}\text { Rice Dry } \\
\text { Season }\end{array}$ & $\mathrm{X} 3$ & $15,409,610$ & $31,840,000$ & No Limit & No Limit & $15,409,610$ \\
\hline
\end{tabular}

The next sensitivity analysis is on a situation where changes in the provision of land resources are used. The sensitivity range of agricultural resources that are included in this binding status can be seen in the completion of the right-hand side ranges (Table 5), which explains the sensitivity of the optimal program value to changes in resource availability or the right-hand value. From the results of the sensitivity analysis in completing the right-hand side ranges, there are 2 binding statuses, namely labor requirements and farming costs. Labor requirements and farming costs are used up in an optimal solution

Table 5. The Value of Agricultural Resource Sensitivity in Right Hand Side Ranges

\begin{tabular}{|c|c|c|c|c|c|c|c|}
\hline \multicolumn{2}{|c|}{ Constraints } & & \multirow{2}{*}{$\begin{array}{c}\text { Lower } \\
\text { Limit }\end{array}$} & \multirow{2}{*}{$\begin{array}{l}\text { Current } \\
\text { Values }\end{array}$} & \multirow{2}{*}{$\begin{array}{l}\text { Upper } \\
\text { Limit }\end{array}$} & \multirow{2}{*}{$\begin{array}{l}\text { Allowable } \\
\text { Increase }\end{array}$} & \multirow{2}{*}{$\begin{array}{l}\text { Allowable } \\
\text { Decrease }\end{array}$} \\
\hline Resources & Unit & Symbol & & & & & \\
\hline Land area & ha & $\mathrm{C} 1$ & $3,497,060$ & 3.500 & No Limit & No Limit & 2,94 \\
\hline $\begin{array}{l}\text { Labour } \\
\text { requires }\end{array}$ & $\mathrm{HOK}$ & $\mathrm{C} 2$ & 0 & 365 & 4,261.6 & 4,261.6 & 269,75 \\
\hline Cost farming & IDR & $\mathrm{C} 3$ & 0 & $37.942,420$ & No Limit & No Limit & $3,249,712$ \\
\hline $\begin{array}{l}\text { Up to take } \\
\text { mung beans } \\
\text { market }\end{array}$ & $\%$ & $\mathrm{C} 4$ & 0 & 0,8 & No Limit & No Limit & 0 \\
\hline
\end{tabular}

The implication is that if farmers can increase their labor requirements and the cost of farming, they can provide higher income for the optimal solution. This is supported by the results of the analysis on the dual solution as previously described (Table 3 ) where the two resources have a shadow price or dual value, which means that each additional resource use of one activity unit will add the solution value by its dual value. 


\section{Conclusions and recommendations}

Farmers use inputs optimally with food crop cropping patterns. Optimizing these inputs, among others namely land use, fertilizers, pesticides, labor, and capital. The land area owned is around 1.44 ha, capable of planting three times a year, namely (1) rainy season rice cropping patterns, (2) mung bean planting patterns, and (3) dry season rice cropping patterns. With a cost of IDR 34,349,763 can generate a gross income of IDR 87,071,590. Optimization of cropping patterns for food crops is achieved by using seeds of new varieties of rice and green beans, optimal use of fertilizers, pest and disease control, and product marketing.

The recommended cropping pattern of food crop maximazing total income of farmers in the Paloh sub-district for the arable area of 0.61 ha is local rice in the rainy season and rice in the dry season of 0.83 ha. To overcome crop failure in the dry season due to lack of water, it is recommended to use a water pump.

\section{References}

1. S. Osama, M.Elkholy, R.M Kansoh, Alexandria Engineering J., 56 (2017)

2. S.S. Chaudhury, D.K. Pattanaik, Jurnal of COATS. https://www.researchgate.net/ publication/316853081. (2016)

3. F. Boustani, H. Mohammadi. Eurasian J. Agric. Environ. Sci., 7 (2010)

4. M. Karamouz, M.R. Tabari, R. Kerachian, B. Zahraie. Proceedings of the World Water and Environmental Resources Congress, Anchorage, Alaska, United States, p 360. (2005)

5. A.M. Alabdulkader, A.I. Al-Amoud, F.S. Awad. Agric. Econ./Zemedelska Ekonomika, 58 (2017)

6. B. Kaur, R.S. Sidhu, K. Vatta, Agricultural Economics Research Revie, 23 (2010)

7. A.B.M. Mostafizur, M.A.U. Zaman, S.M. Shahidullah, M. Nasim, Bangladesh Rice J. 21, 2 (2017)

8. R. Burhansyah, J.C. Kilmanun, M. Puspitasari, E3S Web of Conferences, 232 (2021)

9. R.M, Groves, F.J.Jr. Fowler, M.P. Couper, J.M. Lepkowski, E. Singer, R. Tourangeau, Survey Methodology. (John Wiley and Sons, Inc, 2009)

10. N. Mamun, Disertasion Departemen of Agricultural Economic University of Nigeria, Nsukka. (Departemen of Agricultural Economic University of Nigeria, Nsukka, 2013)

11. J. Weiss, J. Pom-Qm, For Windows Version 3. Software for Decision Sciences: Quantitative Methods, Production and Operations Management. www.prenhall.com/weissdsSoftware@prenhall.com. (2005)

12. BPS Statistic Sambas District. Sambas District in figure 2018. (BPS Statistic Sambas District, 2018)

13. Trustinah, B.S. Radjit, N..Prasetiaswati, D. Harnowo, IPTEK Tanaman Pangan, 9 (2014)

14. O. Eriksson. Linköping University, Department of Mathematics, Statistics. (Linköping University, Faculty of Arts and Sciences, 2007) 